\title{
A THERAPY PROGRAMME FOR PRE-SCHOOL LANGUAGE IMPAIRED CHILDREN*
}

\author{
LINDA NARUN, M.A. (Sp. Path.) (WITWATERSRAND) \\ Department Speech Pathology \& Audiology, \\ University of the Witwatersrand, Johanneshurg
}

\section{$S U M M A R Y$}

This study aimed to establish effective language programmes for pre-school language impaired children based on psycholinguistic principles. Fight language-impaired child ren 6 males and 2 females between the ages of 3 and 6 years, were the subjects. Language samples were transcribed and subjected to syntactic analysis; semantic aspects were also considered and programmes developed for each subject, based on the information obtained from the language analyses. A developmental sequence was adopted as the basis for therapy. A 'slot-method' was used in which language was taught as rule-operated behaviour. Principles of discrimination learning were adopted for teaching some aspects of grammar. Auxiliary verbs are reported in detail as this was the most universal error and difficult to teach. The role of imitation in language learning and the rapy is discussed.

\section{OPSOMMING}

Hierdie studie beoog om doeltreffende taalprogramme vir voorskool se taalgestremde kinders, gebaseer op psigolinguisticse beginsels, daar te stel. Die proefpersone was 8 gestremde kinders, 6 seuns en 2 dogters, tussen die ouderdomme van 3 en 5 jaar. Taalmonsters is getranskribeer en sintakties on tleed; semantiese aspekte is ook in ag geneem. Programme, gebaseer op die gegewens verkry van die taalontledings, is vir elke procfpersoon opgestel. 'n Ontwikkelingsvolgorde is as grondslag vir terapie aanvaar. " $n$,Gleuf' metode is gebruik vir die aanleer van taal as rec̈lbeheerde gedrag. Beginsels van diskrimjnasie-aanleer is gebruik om sekere aspekte van grammatika aan te lecr. Slegs hulpwerkwoorde word uitvoerig bespreek. Foute in hulpwerkwoorde was die mees algemene verskynsel en die_moeilikste om vir die kind aan te leer. Die rol van nabootsing in die aanleer van taal en in taalterapie word bespreek.

In the early years of life, communication occurs primarily through verbal language. The knowledge of, and ability to handle, the mother tongue is of prime importance if any further linguistic codes are to be learnt. Any difficulty with verbal language must consequently affect all other aspects of communication.

We are becoming aware of increasing numbers of young children who exhibit difficulties in acquiring the basic symbolic communication system. Because of the importance of early language learning, it is imperative that more effective methods of intervention be developed. While many studies have been conducted on language acquisition,,${ }^{1,4,8,12,19}$, comparatively few have con-

* This paper is based on an M.A. dissertation submitted to the Department of Speech Pathology and Audiology, University of the Witwatersrand, Johannesburg, 1976. 
cerned themselves with the practical application of this data to the therapeutic situation. Lee ${ }^{10}$ describes the situation thus:

\section{Psycholinguists have not studied atypical language development to any great extent nor have they suggested how to approach clinical problems in language acquisition. The further step of making psycholinguistic in- formation useful and applicable to clinics is going to have to be taken by clinicians themselves.}

The aim of the study was to devise effective therapy programmes based on current psycholinguistic theory. While psycholinguistic research has added much to therapy programmes, language acquisition is still not fully understood, and so advances may not be as great as the volume of literature would have one believe.

Rees ${ }^{17}$ describes several theoretical bases which might be used in deciding the sequence of language therapy. One of these is The Developmental Sequence Basis, which was adopted for the present study. According to Rees, there are two implications inherent in this approach. Firstly, the disordered language must be evaluated against what is expected. Secondly, the child's language goes through predictable stages. During therapy, the child should be taken through these stages, rather than getting him to imitate an adult model. This approach may incorporate syntactic and semantic development. The present study attempted to utilise both aspects, but emphasis was laid on syntactic development. While many aspects of the grammar were diagnosed and treated, this article will deal primarily with the auxiliary verb to $b e$, and sentence types dependent on its correct usage. In addition, factors which appear to influence language learning will be discussed. Ingram ${ }^{5}$ demonstrates that there is a point at which structural aspects can be taught. He states that the problems that language deviant children manifest with the verb to $b e$, are related to performance rather than competence. $\mathrm{He}$ found that these children not only had difficulty in acquiring the form, but also in supplying it when required. However, the sequence of development was the same as for normal children, albeit at a slower rate. Thus, in terms of therapy, data on normal acquisition can be used. Confirming Brown's ${ }^{4}$ findings on the acquisition of $i$ Ingram ${ }^{5}$ suggests first teaching the contractible copula, and then the uncontractible copula, the contractible verbal auxiliary, and lastly, the uncontractible verbal auxiliary. This order is also based on the relative frequency of occurrence of these verb forms.

The importance of the auxiliary verb seems to lie in its necessity as a structural component, without which fully grammatical sentences are not possible. According to Lee, ${ }^{10}$ the elaboration of the verb is one of the most difficult aspects of the English language, because of the introduction of the auxiliary verb. She states that each auxiliary carries a meaning which is superimposed on the meaning of the main verb. However, with regard to the progressive form, Brown, ${ }^{4}$ makes it clear that its semantics is not clearly understood.

Thus, while errors involving the verb to be were viewed predominantly as syntactic errors, it was felt important to make them as meaningful as possible so that acquisition would be facilitated. 
The syntactic realisation of question and negative sentences, is dependent upon a knowledge of the auxiliary verb. The syntactic development of these sentence types has been described fully. ${ }^{9}$ However, the semantic development is understood less well, although Brow ${ }^{4}$ stresses that the development of the wh-question is highly dependent on semantic and cognitive features. Similarly, Bloom ${ }^{1}$ criticised Klima and Bellugi-Klima's study on the grounds that it only considered syntactic development. She has identified three semantic features of negation i.e. non-existance, rejection and denial. A detailed discussion of these features will not be undertaken here. When devising therapy programmes, however, semantic features must be taken into account.

\section{METHOD}

Eight children, two females and six males, between the ages of three and six years, diagnosed at the Speech and Hearing Clinic, University of the Witwatersrand, Johannesburg, as having language learning problems, acted as the subjects in the study. All subjects had normal hearing. In addition, no subject demonstrated any degree of retardation or severe brain injury.

Detailed diagnostic procedures were undertaken with each subject and, from the information obtained, individual therapy programmes devised. These diagnostic procedures were repeated at regular intervals. Any change required in the therapy plan was made, so that diagnosis was on-going throughout the time period allowed for therapy. Spontaneous speech samples of each subject $(S)$ were tape-recorded. Language was elicited in an informal situation, where the Experimenter (E) exposed Ss to meaningful objects and pictures. Immediately following assessment interviews, the tapes were transcribed, so that contextual information could be considered in doing the analysis. Together with the sentence produced by the $S$, the sentence he was attempting was also noted. At times it was difficult to determine exactly what the $S$ had intended to say. It was here that contextual information was utilised in deciding the semantic intention of the sentences. Without this information utterances cannot be adequately analysed or interpreted. . $^{2,4}$

Sentences were assessed using theories of transformational grammar as advocated by Jacobs and Rosenbaum. ${ }^{7}$ However, it was of ten necessary to compare the S's performance with developmental sentence types described by various authorities. ${ }^{10,12,13}$

\section{THERAPY}

Morehead and Johnson ${ }^{15}$ have pointed out that most programmes in speech pathology use learning theory as a basis for instruction. Within this type of approach, the case is presented with a model sentence, is asked to repeat it and given immediate reward.

Most speech and language therapy is structured for direct immediate experience and the unstable changes that occur with the use of this technique are well-known to therapists and generally referred to as "carry over problems. $^{15}$ 
The approach utilised in this procedure hoped to avoid the problems inherent in a behaviourist model, by attempting to teach language as a system of rule-operated behaviour. Regarding language in this framework, it is hypothesised that language deviant children do not extract the rules governing the grammar of the language, as opposed to the normal developing child who somehow learns the semantic restrictions of various linguistic categories. The aim of therapy, therefore, was to enable the Ss to extract and abstract syntactic rules and generalise these rules to novel and creative situations. Thus, the child was not reinforced for a repetition of a model sentence, but rather for being able to generate novel sentences utilising rules taught in therapy. In this way, a 'cognitive' rather than 'behaviourist' approach is used.

Following the initial diagnosis, a therapy programme was devised for each subject. Therapy was conducted over a six month period, during which time each child was seen twice weekly. An attempt was made in devising the therapy programme to establish at what point during the acquisition of syntax, the child had made an incorrect hypothesis in the learning of syntactic rules. Each programme was devised to stimulate the child at the point at which he failed to establish correct phrase structure rules and to enable him to "relearn' parts of the grammar which were dependent on the acquisition of these earlier rules. A 'slot method' was employed in an attempt to demonstrate the rule that the $S$ had failed to acquire. It was felt that if imitation of a constant structure could be established (where the syntactic structures and semantic relations were held constant) the $\mathrm{S}$ might abstract the rule operating and generalise it to new creative utterances. Thus the basic structure of the sentence was held constant and the lexical item of one category varied in order to demonstrate the rule which gave rise to the underlying meaning of the sentence. The subject was presented with many sentences illustrating one aspect of a sentence before any response was demanded. In utilising the slot method, stimulation was not only through the auditory modality, but through the visual modality as well. Therefore, verbal stimuli were always associated with visual stimuli, arranged sequentially, in an at tempt to heighten awareness of auditory sequencing of a sentence.

In some instances it was difficult to apply the slot method utilising visual stimuli as described above. An example of this was in the teaching of the present progressive construction. When teaching this construction the therapist and the $S$ carried out the continuous action in unison with the verbal counterpart.

When acquiring the phonological system children learn the differencé between phonemes rather than discreet features. This theoretical framework was utilised in teaching aspects of syntax. In the case of tenses, an attempt was made to demonstrate the difference between, for example, an action that was ongoing and one that had already taken place. Therefore, the child carried out the activity "Johnny is jumping" while he verbalised it, and afterwards said "Johnny jumped", indicating that the activity had already occurred. Alternatively, the future tense was used preceding the introduction of the present progressive. In this way, the different tenses were semantically and syntactically contrasted. 
Data was evaluated qualitatively rather than subjected to a statistical analysis. The linguistic performance of language impaired children tends to be inconsistent. The nature of these inconsistencies is important and forms an integral part of making therapeutic decisions. In evaluating the efficacy of therapeutic procedures, initial and final language samples were compared.

\section{RESULTS}

The primary aim of this study was to investigate a method of therapy. However, the diagnostic procedures undertaken prior to the development of therapeutic programmes in themselves yielded interesting results. In addition, the therapy programmes depended on these results, so that the diagnostic findings will also be reported.

The results confirm those of Morehead and Ingram, ${ }^{14}$ who found that a significant discriminating factor between language impaired and young normal children is the restricted ability of deviant children "to develop and select grammatical and semantic features which allow existent and new major lexical categories to be assigned to larger sets of syntactic frames.' Morehead and Ingram see these restricted sentences and sentence types as being reflective of a cognitive deficit. An example of the restricted sentence types used by the Ss in this study are $w h$-questions. No subject used all possible wh-word questions. The only two types used by most subjects with any consistency were where and what.

The study analysed many aspects of syntax, e.g. prepositions and prepositional phrases, pronouns, articles. However, as stated earlier, only auxiliaries will be discussed and to a lesser extent sentence types dependent upon their realisation.

\section{DIAGNOSTIC RESULTS}

All Ss demonstrated errors in the use of the auxiliary verb system. The use of the present progressive construction be + ing confirmed previous observations by Lee, ${ }^{10}$ in that the inflection -ing was never omitted, but the auxiliary was always omitted. According to her, in the course of normal develop-. ment -ing emerges very early and is later followed by the auxiliary. The language impaired child, therefore, seems to follow the normal course of verb acquisition, but in a typically delayed manner. Brown ${ }^{4}$ in comparing Adam and Eve's performance on the auxiliary with Labov's work, found that the normal child may omit auxiliaries (or copulas) which can be contracted but not those which cannot be contracted. However, on the rare occasions that the auxiliary was used by some Ss, the findings of Brown (on normal children) were not demonstrated. These language impaired children, only used contracted auxiliaries (and copulas). These isolated examples of the usage of the auxiliary, did not appear to reflect the child's competence to handle this node for two reasons: (i) The sentences in which the auxiliary appeared, seemed to be imitated forms i.e. stock sentences which the mother may often have used, e.g. I'm big, I'm good. All examples seemed to be of this type. (ii) Within the samples, auxiliaries were used very infrequently and in restricted sentence types, i.e. declarative sentences almost exclusively. 
Menyuk $^{13}$ has pointed out that, although all developing behaviour is inconsistent, the normal child tends to use the correct construction with greater frequency than the incorrect construction. In contrast, the language impaired child in this study used the incorrect construction with far greater frequency. In addition, Brown ${ }^{4}$ has stressed that frequency must be assessed together with diversity of type. The results of this study demonstrate the very restricted occurrence of this verb.

By attaching -ing to the verb, the child has marked the class, as well as the continuing action. The semantic loading of $b e$ is very low and the child communicates no more meaning by using it. As the child uses language to com- . municate his cognitions, he cannot be expected to use a linguistic form until he understand it. ${ }^{19}$ As Brown ${ }^{4}$ has pointed out, the young child using socalled 'telegraphic' speech can be understood very easily. Including functors does not really add significantly to the child's message. However, the normal child very quickly incorporates functional words into his utterances, whereas the language impaired child fails to do so. Auxiliaries are but one example of this failure. It seems possible that auxiliaries and their development are related to the cognitive deficit postulated earlier. Therefore, because this verb has so little meaning, therapy should attempt to make it more meaningful.

\section{THERAPY RESULTS}

The verb to be proved to be a very difficutl construction to teach and took a great deal of time. Lee ${ }^{10}$ has suggested that more meaning can be brought to this verb by teaching questions and negatives first, where the necessity for the verb is more easily demonstrated. If this procedure had been adopted, therapy time required may have been significantly reduced. However, having taught it in this manner an interesting result was observed. Once the Ss could use this verb correctly, questions and negative transformations spontaneously improved. No $\mathrm{S}$ had to be given therapy specifically dealing with these two transformations. Why this occurred, is difficult to explain. However, it confirms that the Ss did not have difficulty with questioning or negation per se, but with the syntactic structure involved in the formulation of these sentence types. This does not, however, explain how the child was able to transpose the auxiliary and the subject by merely acquiring the auxiliary verb.

Errors involving the verb to be were the most frequent, in that this verb was deviant in all Ss and only very infrequently was it used correctly. It was the base line of therapy with all Ss, because of its universal nature and because so many other constructions were affected by it. At the end of the sixmonth period allowed for therapy, five of the eight Ss handled this node quite competently. The remaining three subjects experienced difficulty in generalising the auxiliary to new situations. After many repetitions of the construction, they were able to imitate it, but had difficulty in generating new utterances. It would seem that these subjects had difficulty in abstracting and generalising the rule governing auxiliaries. Again this particular difficulty seems to indicate a cognitive deficit in these particular Ss.

\section{GENERAL DISCUSSION}

The verb to be both as an auxiliary and a copula proved to be a difficult 
construction to teach. Lee ${ }^{10}$ suggests that because it has a low semantic value, its acquisition is difficult. It is the therapist's task to increase the meaning of this node if it is to be adequately taught. The method employed in this experimental procedure i.e. the use of contrastive tenses together with the appropriate actions did seem to highlight this verb. The refore, this broadly syntactic approach was successful in that the children incorporated the structure into their utterances. This led to the correct usage of many sentence types.

After many repetitions of this construction, Ss were able to imitate it. Immediately following these repetitious presentations, the Ss were able to produce it spontaneously. For those Ss who encountered difficulty the problem arose when they used this construction at a later time, when not specifically stimulated. It was thus the 'carry-over' and 'generation' of sentences involving the present progressive construction which invariably proved to be the point of difficulty.

An at tempt was made when teaching all aspects of language not to reward imitated utterances, but.rather the child's attempt to produce a spontaneous utterance, thereby reducing the role of imitation in the learning process. However, it is extremely difficult to avoid imitation, and invariably it becomes an inherent part of the teaching programme. Bricker \& Bricker ${ }^{3}$ make it clear that

Imitation is one of the more powerful language training tools and the parameters need to be studied if this process is to be used efficiently in training.

From the discussion on the auxiliary verb, it can be seen that the ability to imitate a given construction, does not imply that the child is able to use it. Ruder and Smith ${ }^{18}$ demonstrated that what is important is that both comprehension and imitation training are required to achieve production, and it is not significant which is done in the initial stages of therapy.

The language impaired children studied, and in particular the three subjects whose improvement was minimal, had difficulty in imitating. The normal developing child imitates parents and siblings on verbal and non verbal tasks with ease and pleasure. The Ss experienced difficulty on all levels of imitation, and had to be 'taught' to do what is usually spontaneous behaviour. It may prove fruitful to view this inability of the language impaired child from a Piagetian point of view. Piaget ${ }^{16}$ regards all symbolic play and mental imagery as being derived from motor imitation, so that the language impaired child's inability to imitate may be representative of a cognitive deficit. If so, language intervention should begin with motor imitation tasks and only later proceed to verbal material.

Viewing child language syntactically, is limited in that it does not account for the possible restricted nature of the utterances. Therefore while five Ss were considered to be 'syntactically rehabilitated' (three children still displayed syntactic errors), it must be emphasised that attention was not paid to what the Ss did not express. Consequently, the language may not have been semantically diversified. As Ingram ${ }^{6}$ states 
... we may have to shift from worrying about how correctly these children speak to what they have to say. In doing such, we need to face the problems of whether or not teaching syntax will help cognitive development...

The diagnosis and treatment of wh-questions illustrates this point. Syntactic form of questions improved as a result of the acquisition of the auxiliary. Note was not made of the change (if any) that occurred in the type of questions asked. Developmentally, some wh-questions emerge before others. lt is the task of the therapist to diagnose and treat any deficits which may occur on this, the semantic level. Therefore, in order for any therapy programme to be successful, language must be considered at all levels i.e. phonological, syntactic and semantic. Although five $S$ s are described as rehabilitated, this must be regarded tentatively as an assessment of rehabilitation can only be made longitudinally. Marge ${ }^{11}$ outlines five secondary goals of a language programme. One of these is " ... provision of a linguistic foundation for the further development of language skills, such as reading and writing." "The E feels that in many ways an assessment of rehabilitation is false, unless the therapist is sure that the child will cope in the educational and social fields. The language pathologist must not only ensure that the child is talking, but that the development of secondary symbolic systems, which are dependent on language, is adequate. If our therapy programmes do not facilitate future learning, we must accept Lenneberg's assertion that language intervention should be left as late as possible so that maturation can occur (cited by Marge ${ }^{11}$ ).

Any programme developed to aid a language impaired child should attempt to isolate these possible future difficulties and provide treatment for them as early as possible. Clearly, this area requires a great deal more research and it is possible that the child may require many programmes rather than one focused only on his linguistic abilities.

\section{REFERENCES}

1. Bloom, L. (1970): Language Development: Form \& Function in Emerging Grammars; Cambridge, Massachusetts \& London, England, The M.I.T. Press.

2. Bloom, L. (1973): One Word at a Time; The Hague, Paris: Mouton.

3. Bricker, W.A. \& Bricker, D.D. (1974): An Early Language Training Strategy. In Language Perspectives - Acquisition, Retardation and Intervention; Eds., Schiefelbusch, L. \& Lloyd, L.L. Baltimore: University Park Press.

4. Brown, R. (1973): A First Language: The Early Stages. Cambridge, Massachusetts: Harvard University Press.

5. Ingram, D. (1972a): The Acquisition of the English Verbal Auxiliary \& Copula in Normal and Linguistically Deviant Children. Papers \& Reports in Child Language. Stanford University.

6. Ingram, D. (1972b): The Acquisition of Questions \& its Relation to Cognitive Development in Normal \& Linguistically Deviant Children A PilotStudy: Papers and Reports on Child Language; Stanford University. 
7. Jacobs, R.A. \& Rosenbaum, P.S. (1970): Readings in English Transformational Grammar. Massachusetts, Toronto, London. Ginn \& Co.

8. Jakobson, R. \& Halle, M. (1971): Fundamentals of Language. The Hague, Paris: Mouton.

9. Klima, E.S. \& Bellugi-Klima, U. (1966): Syntactic Regularities in the Speech of Children. In Child Language: $A$ Book of Readings. Eds. BarAdon, A. \& Leopold, W.F. Engelwood Cliffs, New Jersey, Prentice Hall, 1971: 412-423. Reprinted from Psycholinguistic Papers; Eds. Lyons, J. \& Wales, R.J.

10. Lee, L.L. (1974): Developmental Sentence Analysis. Evanston: Northwestern University Press.

11. Marge, M. (1972): General Problem of Management and Corrective Education. In Principles of Childhood Language Disabilities; Eds. Irwin. J.V.\& Marge, M. New York; Appleton-Century-Croft, Meredith Corp.

12. McNeill, D. (1970): The Acquisition of Language. The Study of Developmental Psycholinguistics: New York, Harper \& Row.

13. Menyuk, P. (1969): Sentences Children Use. Cambridge, Massachusetts: M.I.T. Press.

14. Morehead, D.M. \& Ingram, D. (1973): The Development of Base Syntax in Normal and Linguistically Deviant Children. J. Speech Hear. Research, 16:330-352.

15. Morehead, D.M. \& Johnson, M. (1972): Piaget's Theory of Intelligence Applied to the Assessment and Treatment of Linguistically Deviant Children. Papers \& Reports on Child Language. Stanford University.

16. Piaget, J. (1972): Language \& Thought from the Genetic Point of View. In Language in Thinking. Ed. Adams, P. Penguin Books Ltd.

17. Rees, N.S. (1972): Bases of Decision in Language Training. J. Speech Hear. Dis., 37, 283-304.

18. Ruder, K.F. \& Smith, M.D. (1974): Issues in Language Training. In Language Perspectives - Acquisition, Retardation and Intervention. Eds. Schiefelbusch, R.L. \& Lloyd, L.L., Baltimore, London \& Tokyo: University Park Press.

19. Slobin, D.1. (1970): Universals of Grammatical Development in Children. In Advances in Psycholinguistics Eds. Flores D'Arcais, G.B. \& Levelt, W.J.M., Amsterdam, London: North Holland Publishing Co. 


\section{Philins Hearing Aid Services}

A Division of S.A. Philips (Pty) Ltd.

\section{hearing aids \\ portable \\ audiometers}

\section{group teachin
systems}

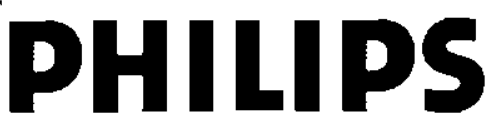

HEARING AID SERVICES

Head Office 1005 Cavendish Chámbers, 183 Jeppe Street, P.O. Box 3069, JOHANNESBURG.

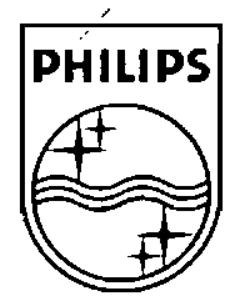

